\title{
Ectomycorrhizal communities associated with silver fir seedlings (Abies alba Mill.) differ largely in mature silver fir stands and in Scots pine forecrops
}

\author{
Rafal Ważny
}

Received: 28 August 2013 / Accepted: 14 April 2014 / Published online: 14 May 2014

(C) The Author(s) 2014. This article is published with open access at Springerlink.com

\begin{abstract}
- Context The requirement for rebuilding forecrop stands besides replacement of meadow vegetation with forest plants and formation of soil humus is the presence of a compatible ectomycorrhizal (ECM) fungal community.

- Aims This study aims to assess ectomycorrhizal fungi diversity associated with silver fir (Abies alba Mill.) seedlings regenerating in silver fir stands and Scots pine forecrops.

- Methods One-year-old seedlings were sampled in six study sites: three mature fir forests and three pine forests. ECM fungi were identified by polymerase chain reaction amplification and sequencing of the internal transcribed spacer of rDNA.

- Results The mean mycorrhizal colonization exceeded $90 \%$. Thirty-six ectomycorrhizal taxa were identified in fir stands and 23 in pine forecrops; ten out of these species were common to both stands. The fungal communities were different between study sites $(R=0.1721, p=0.0001)$. Tomentella stuposa was the only species present at all sites.

- Conclusion Silver fir seedlings in Scots pine forecrops supported smaller ECM fungal communities than communities identified in mature silver fir stands. Nevertheless, fungal
\end{abstract}

Handling Editor: Ana Rincon

Electronic supplementary material The online version of this article (doi:10.1007/s13595-014-0378-0) contains supplementary material, which is available to authorized users.

\footnotetext{
R. Ważny

Institute of Environmental Sciences, Jagiellonian University,

ul. Gronostajowa 7, 30-387 Kraków, Poland

Present Address:

R. Ważny $(\triangle)$

Malopolska Centre of Biotechnology, Jagiellonian University, ul. Gronostajowa 7A, 30-387 Kraków, Poland

e-mail: rafal.wazny@uj.edu.pl
}

colonization of seedling roots was similar in both cases. This suggests that pine stands afforested on formerly arable land bear enough ECM species to allow survival and growth of silver fir seedlings.

Keywords Ectomycorrhiza (ECM) · Forecrop rebuilding · Molecular identification $\cdot$ Scots pine $\cdot$ Silver fir

\section{Introduction}

Silver fir (Abies alba Mill.) is widely distributed across the European highlands and is one of the most important forest trees in the mountainous regions of Poland. Silver fir is predominant in the foothills and lower subalpine regions of the Carpathians and forms monocultured and mixed forests with Picea abies L. and Fagus sylvatica L. (Horvat et al. 1974). The understory light regime is an essential environmental condition for the regeneration and survival of the silver fir. Seedlings and saplings require only $15-25 \%$ of full light (Jaworski 2011), which dictates the methods available for regeneration and cultivation during the young stage of the fir beneath the understory. Thus, during silviculture, silver fir should be preceded by forecrop stands that provide shading for the seedlings; it cannot be introduced as the first generation on formerly cultivated areas. The conditions required for the regeneration of silver fir seedlings are usually found in Scots pine (Pinus sylvestris L.) and European larch (Larix decidua Mill.) stands (Dobrowolska 2008).

Since the middle of the twentieth century, some of the former arable areas in the Polish Carpathians have been afforested with Scots pine and European larch as forecrop stands. These stands have reached the age of rebuilding, which occurs by natural seed regeneration of silver fir from adjacent stands or by planting seedlings under the canopy of 
pine stands. Silver fir is ectomycorrhizal (ECM) (Trappe 1962). ECM fungi colonize new seedlings and protect them against root disease ensuring healthy seedling growth (Marx 1969) and are involved in the process of regeneration of the plants and sustainability of ecosystems; this increases seedling survival of the silver fir (Perry et al. 1989). The current knowledge of silver fir symbionts is predominantly based on morphological and anatomical descriptions of ectomycorrhizas (Agerer 19872007; Berndt et al. 1990; Comandini et al. 1998, 2001; De Román et al. 2005; Dominik 1961; Farfał 2008; Kowalski 1982, 2008; Kowalski et al. 1996; Pachlewski 1955; Stępniewska and Rębisz 2004) and fungal fruiting bodies (Laganà et al. 1999, 2002). Few molecular investigations of the ECM symbionts that associate with silver fir seedlings appear in the literature (Cremer et al. 2009; Eberhardt et al. 2000; Smutek et al. 2010; Ważny 2011).

The requirements for rebuilding forecrop stands are (a) replacement of meadow vegetation with forest plants, (b) formation of soil humus because soil microorganisms hasten the decay of plant tissues, and (c) the formation of ectomycorrhizas on tree roots (Jaworski 2000). At one site in the Carpathians, $3 \mathrm{~cm}$ of soil humus had formed 30 years after meadow afforestation with Scots pine (Maciaszek and Zwydak 1996). Farfał (2008) and Kowalski et al. (1996) described the morphological and anatomical features of ectomycorrhizas of the silver fir seedlings regenerating in pine stands, although ECM fungal symbionts have not been identified.

Two hypotheses were developed: (a) the diversity of ECM communities of silver fir seedlings is higher in mature silver fir seedling forecrops than in Scots pine forecrops and (b) ECM colonization of roots in forecrop stands is elevated ensuring seedlings survival and successful rebuilding of pine forecrops. Molecular methods were used in this study to identify the fungal species associated with silver fir seedlings regenerating in fir stands and pine forecrops, which are potentially relevant to the subsequent steps in ecological succession towards a mature silver fir stand.

\section{Materials and methods}

\subsection{Study sites}

Three silver fir (A. alba) stands (F1, F2, and F3) and three Scots pine (P. sylvestris) stands (P1, $\mathrm{P} 2$, and $\mathrm{P} 3)$ with natural regeneration of silver fir seedlings were selected for investigation. Each pine stand was adjacent to at least one fir stand and was established on an abandoned area after cultivation. Several woody and herbaceous plants, such as P. abies (L.) H. Karst, F. sylvatica L., Acer pseudoplatanus L., Corylus avellana L., Dentaria glandulosa Waldst. and Kit., Galium odoratum (L.)

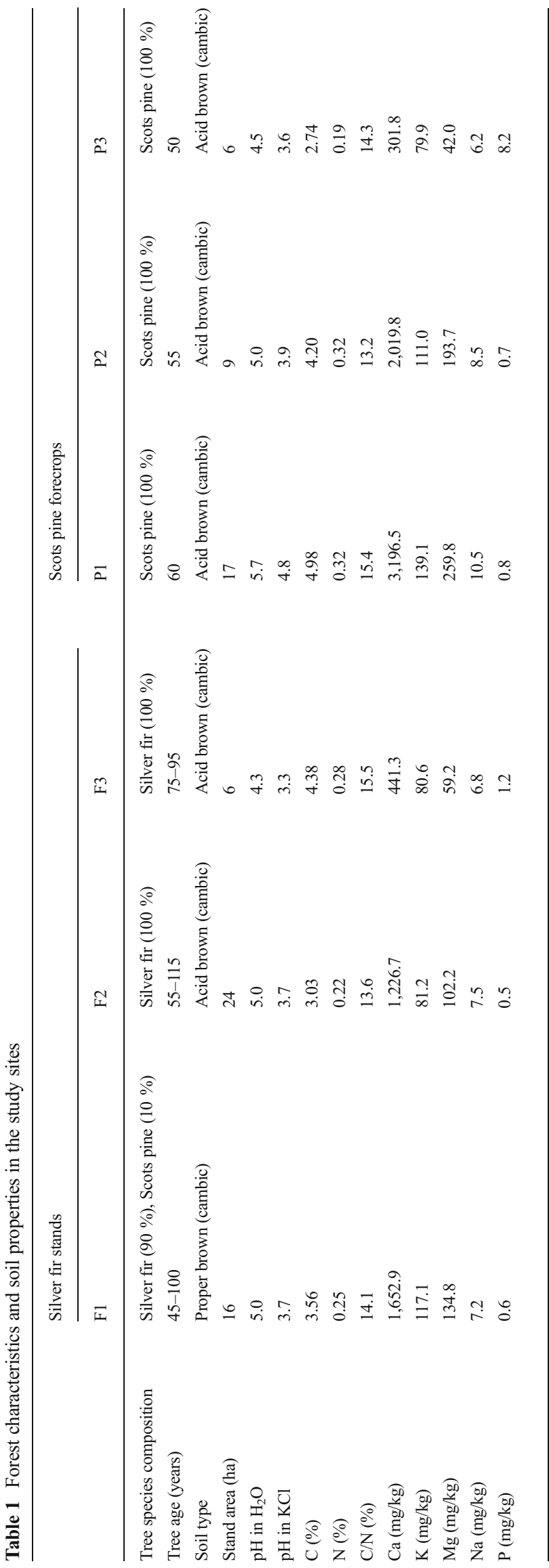


Scop., Paris quadrifolia L., and Maianthemum bifolium (L.) F. W. Schmidt, were sparsely distributed in the understory and fir seedlings of between 1 and 20 years old had regenerated in each stand. The stands were located in the Experimental Forestry Unit in Krynica (southern Poland: $49^{\circ} 21^{\prime} \mathrm{N}, 20^{\circ} 58^{\prime}$ E). Table 1 presents their characteristics. For ECM analysis, 30 1 -year-old seedlings were sampled from each site in autumn 2010 along transects spaced 10-20 m apart with minimum intervals of $10 \mathrm{~m}$ between adjacent seedlings. Seedlings were sampled in an area of 6 ha in each of the stands. The seedlings were collected together with adjacent soil, placed in plastics bags, and stored at $-20{ }^{\circ} \mathrm{C}$ until analysis. In addition, in each stand, one bulk soil sample (each being composed of 10 subsamples) was collected for chemical analysis.

\subsection{Seedling parameters}

The following data were collected: number of mycorrhizal seedlings, number of live and dead ectomycorrhizas and nonmycorrhizal roots, height and diameter of shoot, and dry weight of shoot and root.

\subsection{ECM assessments}

The root system was gently washed in tap water to remove organic and mineral soil. Different morphotypes of ectomycorrhizas were selected according to characteristics as mentioned by Agerer (1987-2007). Mycorrhizal colonization was confirmed by microscopic examination (Reichert, Austria). For the same morphotypes from each site, two to six root tips were placed in cetyl trimethyl ammonium bromide. DNA extraction was performed according to Lanfranco et al. (1998) with a minor modification (chloroform was not used and DNA was diluted in water). Amplification of the internal transcribed spacer (ITS) rDNA region was carried out with ITS1F (Gardes and Bruns 1993) and ITS4 (White et al. 1990) primers. The reagents of the polymerase chain reaction (PCR) and their final concentrations were: $1 \times$ Pol Buffer,
$0.2 \mathrm{mM}$ dNTPs (each), $50 \mathrm{pmol}$ of each primer, and 1 unit Taq DNA polymerase (Eurx).

PCR conditions were as follows: initial denaturation $10 \mathrm{~min}$ at $93{ }^{\circ} \mathrm{C}$ followed by 35 cycles consisting of $1-\mathrm{min}$ denaturation at $95^{\circ} \mathrm{C}, 1$-min annealing at $60^{\circ} \mathrm{C}, 2$-min extension at $72{ }^{\circ} \mathrm{C}$, and 10 -min final extension at $72{ }^{\circ} \mathrm{C}$. The presence of amplified products was visualized in $1.5 \%$ agarose gel stained with ethidium bromide. Sequencing was carried out at the Laboratory of Molecular Biology of Adam Mickiewicz University in Poznan, Poland. The ITS4 primer was used for reading sequences. The sequences were edited using BioEdit (Hall 1999) and Chromas (www.technelysium. com.au) software and then compared with published sequences in UNITE (Abarenkov et al. 2010) and NCBI (www.ncbi.nlm.nih.gov) databases. A positive identification of a mycorrhizal species was confirmed if they shared $\geq 98 \%$ ITS region sequence identity with the most similar (reference) sequence from the UNITE or NCBI databases. The obtained sequences within $2 \%$ nucleotide difference were categorized as a single operational unit and assigned an identical name.

\subsection{Soil assessment}

The $\mathrm{pH}$ was determined in $\mathrm{H}_{2} \mathrm{O}$ and $\mathrm{KCl}$, the $\mathrm{C}$ content was analyzed by the Tiurin method, the $\mathrm{N}$ content by Kjeldahl method, and the macronutrient $(\mathrm{Ca}, \mathrm{K}, \mathrm{Mg}, \mathrm{Na})$ content in the soil was determined in $1 \mathrm{M} \mathrm{CH}_{3} \mathrm{COONH}_{4}$ with the spectrophotometer ICP-OES Thermo iCAP 6500 DUO (Ostrowska et al. 1991).

\subsection{Data analysis}

Statistical analysis was performed with the parametric $t$ test and non-parametric Mann-Whitney $U$ test using Statistica 10.0 (StatSoft 2011) at the level of significance $\alpha=0.05$. The non-parametric test was used because normality through the Shapiro-Wilk test and homogeneity of variance by the Levene's test were not always found. Communities of ECM fungi were described by species richness (number of identified

Table 2 Parameters of shoots and roots of 1-year-old Abies alba seedlings regenerating in fir stands (F) and pine forecrops (P)

\begin{tabular}{lllllllll}
\hline Parameter & F1 & F2 & F3 & P1 & P2 & P3 & F & P \\
\hline Height (cm) & 4.64 & 4.96 & 5.06 & 4.76 & 4.43 & 4.82 & $4.89 \mathrm{a}^{\mathrm{a}}$ & $4.67 \mathrm{a}$ \\
Diameter (mm) & 0.82 & 0.98 & 0.98 & 0.88 & 0.98 & 0.89 & $0.93 \mathrm{a}^{\mathrm{a}}$ & $0.92 \mathrm{a}$ \\
Dry weight (g) & 0.039 & 0.061 & 0.050 & 0.040 & 0.050 & 0.040 & $0.050 \mathrm{a}^{\mathrm{a}}$ & $0.042 \mathrm{~b}$ \\
Mycorrhizal seedlings (\%) & 90.0 & 96.7 & 100.0 & 96.7 & 93.3 & 83.3 & 95.6 & 91.1 \\
Live mycorrhizas (\%) & 79.4 & 99.7 & 100.0 & 81.8 & 97.8 & 88.6 & 93.0 \\
Non-mycorrhizal roots (\%) & 18.9 & 0.3 & 0.0 & 18.2 & 2.2 & 0.6 & 6.4 & 89.4 \\
Dead mycorrhizas (\%) & 1.7 & 0.0 & 0.0 & 0.0 & 0.0 & 10.8 & 0.6 & 3.0 \\
\hline
\end{tabular}

${ }^{a}$ Numbers with the same letters indicate lack of statistical differences between $\mathrm{F}$ and $\mathrm{P}$ sites 
Table 3 Diversity of ectomycorrhizal fungal communities colonizing 1-year-old Abies alba seedlings in fir stands (F) and pine forecrops $(\mathrm{P})$

\begin{tabular}{lllllllll}
\hline Diversity parameter & F1 & F2 & F3 & P1 & P2 & P3 & F & P \\
\hline Richness per site & 13 & 14 & 22 & 9 & 7 & 12 & 36 & 23 \\
Richness per seedlings & 1.7 & 2.3 & 3.3 & 1.5 & 1.4 & 1.5 & 2.4 & 1.5 \\
Shannon-Wiener $\left(H^{\prime}\right)$ & 2.32 & 2.29 & 2.44 & 1.67 & 1.78 & 2.10 & 2.94 & 2.71 \\
Simpson $(1-D)$ & 0.88 & 0.87 & 0.85 & 0.74 & 0.81 & 0.83 & 0.91 & 0.90 \\
Evenness $\left(e^{\wedge} H / S\right)$ & 0.78 & 0.71 & 0.52 & 0.59 & 0.84 & 0.68 & 0.52 & 0.65 \\
\hline
\end{tabular}

mycorrhizal taxa), relative abundance (number of mycorrhizas of a given mycorrhizal species per total number of mycorrhizas in each site), and frequency (ratio of number of seedlings with given ECM taxa to total number of seedlings in each stand). To assess whether a sufficient number of samples were collected, the observed species accumulation curve and jackknife first-degree estimator curve with 100 randomization with sample replacement (allowing comparison of Sobs F with Sobs $\mathrm{P} t$ test) were plotted in the Estimates 8.2.0 program (Colwell 2006). To assess the ECM species diversity, Shannon-Wiener's $\left(H^{\prime}\right)$, Simpson's $(1-D)$, and evenness $\left(e^{\wedge} H / S\right)$ indicators were performed. The above coefficients, the analysis of similarities (ANOSIM), and the non-metric multidimensional scaling (NMDS) analysis were calculated in PAST 1.89 (Hammer et al. 2001). ANOSIM was used as an analysis of similarity to determine if the fungal symbionts communities differed between study sites. The variability of ECM composition among seedlings of different forest stands was visually modeled using NMDS. For ANOSIM and NMDS analyses standardized relative abundance data of each taxa after square root transformation was used. The above mentioned analyses were based on the Bray-Curtis coefficient (Bray and Curtis 1957).

\section{Results}

\subsection{Seedling parameters}

Mean heights of seedlings were $4.89 \mathrm{~cm}$ in the fir stands and $4.67 \mathrm{~cm}$ in the pine stands and were not significantly different. Mean diameter of seedlings did not differ between seedlings regenerating in the fir and pine stands. The dry weight of fir seedlings in the fir stands was statistically higher than that of seedlings in the pine stands (Table 2).

\subsection{ECM colonization}

A high mean percentage of mycorrhizas were observed in both types of seedlings (95.6\% in fir stands and $91.1 \%$ in pine stands) and live ectomycorrhizas (93.0 and $89.4 \%$, respectively) in both groups of sites. The mean percentage of dead mycorrhizas was $0.6 \%$ in the fir stands and $3.6 \%$ in the pine forecrops (Table 2).

Sequencing analysis revealed a total of 49 mycorrhizal taxa on $A$. alba seedlings (Supplementary Table 1); 36 taxa were present on fir seedlings regenerating in the fir stands, and 23 taxa were present on fir seedlings regenerating in the pine forecrops (Table 3). The jackknife species richness values were estimated as 42 and 25, respectively (Fig. 1). Hence, the observed number of taxa was $86 \%$ of the estimated richness in fir stands and $92 \%$ of the estimated number of ECM species in pine forecrops. The observed number of ECM taxa in the fir stands was significantly higher than that in the pine forecrops $(p=0.0001)$. Ten out of 49 taxa $(20 \%)$ were common to both stands. Thirty-one ECM taxa were identified to the species level (Supplementary Table 1, Fig. 2). Three morphotypes were not matched to any taxa; one of which was a brown ectomycorrhiza with a Hartig net and without a mantle (Supplementary Table 2). Molecular analysis revealed that this morphotype was formed by various taxa, which included Russula integra, Thelephora terrestris, Tylospora sp., and Xerocomus badius (data not published).

Species richness per site was higher in particular fir stands (13-22) than in pine (7-12) stands, showing similarity to the mean species richness per one seedling (Table 3). The Shannon-Wiener and Simpson's indices were higher for fir

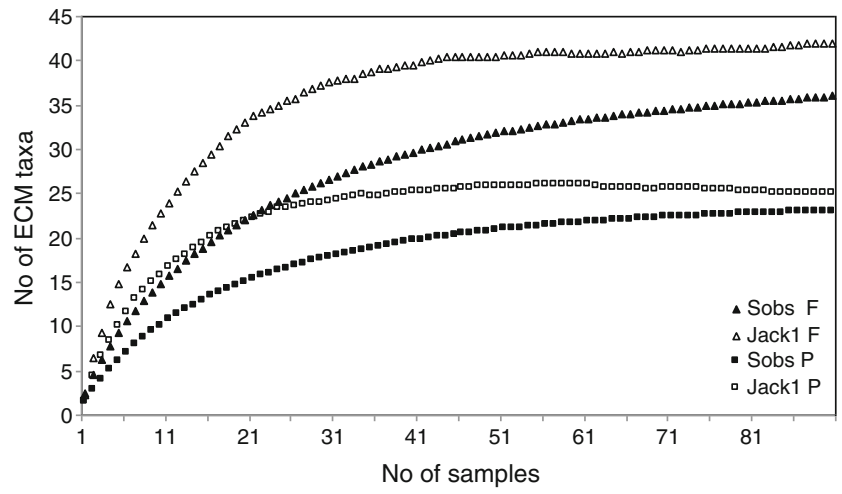

Fig. 1 Ectomycorrhizal species richness estimation curves for 1-year-old Abies alba seedlings regenerating in fir $(F)$ and pine $(P)$ stands. Sobsspecies observed, Jack1-first order jackknife estimator (100 randomized runs with sample replacement were used) 
stands $(2.29-2.44$ and $0.85-0.88)$ than for pine forecrops (1.67-2.10 and 0.74-0.83), respectively (Table 3 ).

Tomentella stuposa was the only species present at all sites, followed by Cenococcum geophilum noted in four stands
(Table 4). R. integra, Clavulina cristata, Tylospora asterophora, Tuber puberulum, and Clavulina sp.1 were also commonly occurring species and noted at half of the investigated sites (Table 4). The most abundant species on seedlings
Fig. 2 Morphological features of selected ectomycorrhizas observed on 1-year-old Abies alba seedlings (magnification 20-40×)

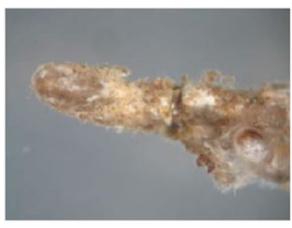

Amanita muscaria

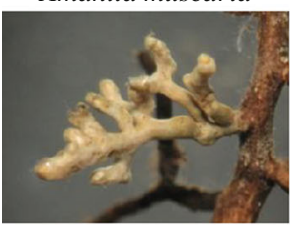

Boletus pruinatus

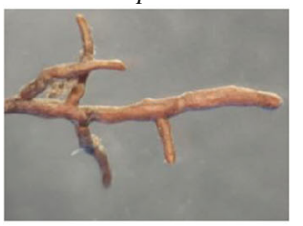

Elaphomyces muricatus

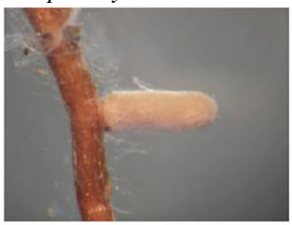

Laccaria amethystina

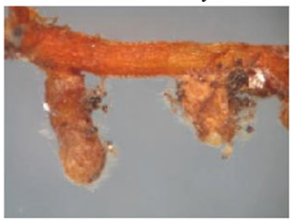

Paxillus involutus

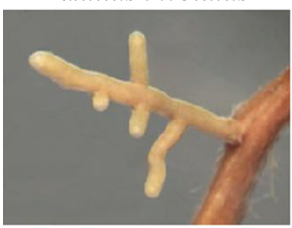

Russula integra

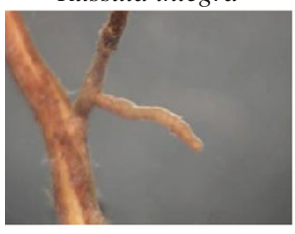

Russula xerampelina

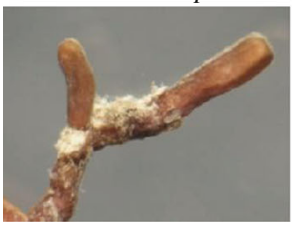

Tuber puberulum

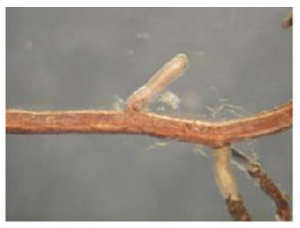

Amanita spissa

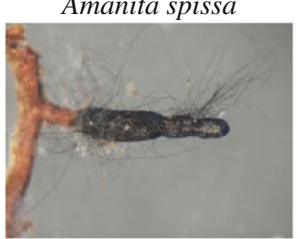

Cenococcum geophilum

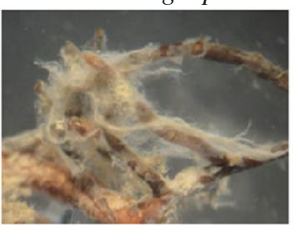

Hydnum repandum

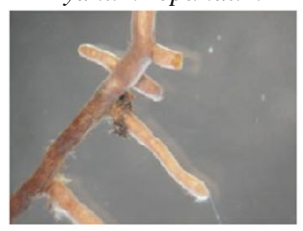

Laccaria maritima

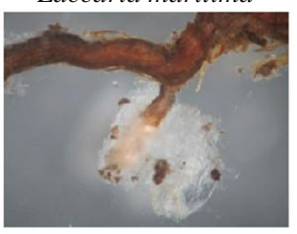

Piloderma byssinum

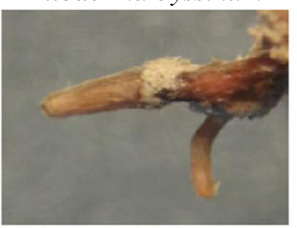

Russula nigricans

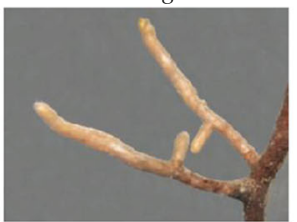

Thelephora terrestris

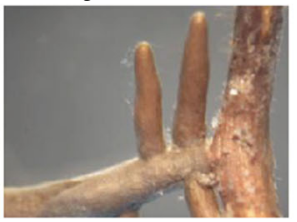

Tylospora asterophora

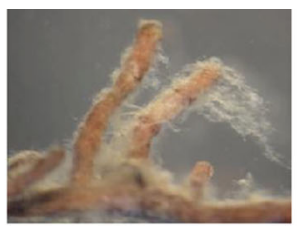

Amphinema byssoides

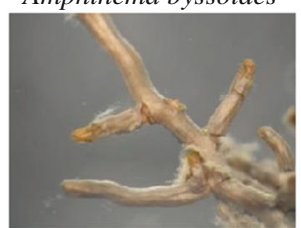

Clavulina cristata

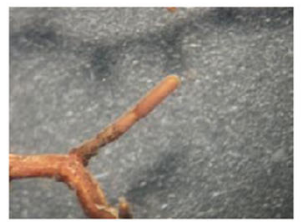

Hydnum rufescens

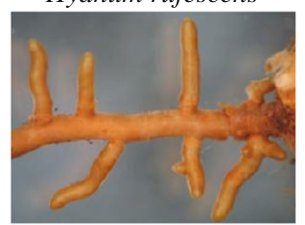

Lactarius aurantiacus

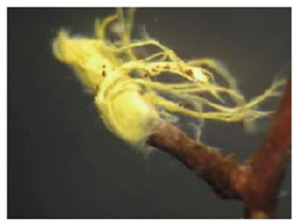

Piloderma fallax

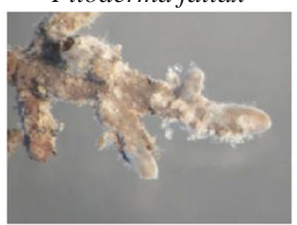

Russula olivacea

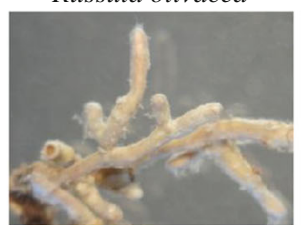

Tomentella ellisii

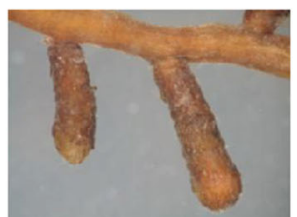

Unidentified fungus 1

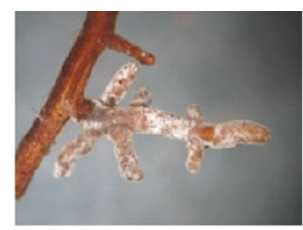

Boletus edulis

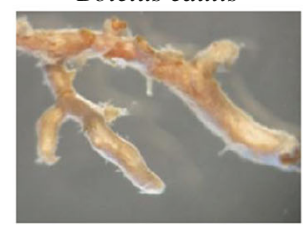

Clavulina rugosa

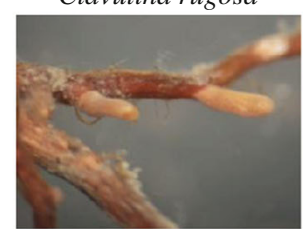

Inocybe terrigena

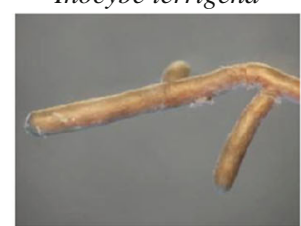

Lactarius salmonicolor

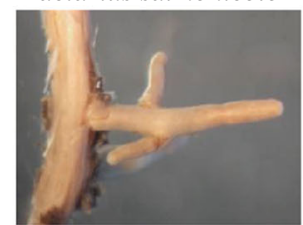

Russula amethystina

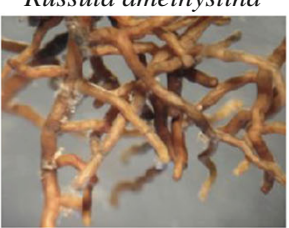

Russula puellaris

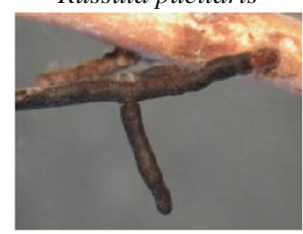

Tomentella stuposa

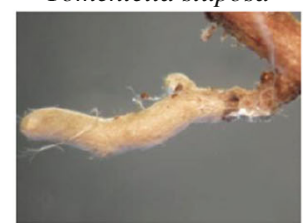

Xerocomus badius 
Table 4 Relative abundance (RA) and frequency (FR) of ectomycorrhizal taxa on the roots of 1-year-old Abies alba seedlings regenerating in fir stands (F1, F2, F3) and pine forecrops (P1, P2, P3)

\begin{tabular}{|c|c|c|c|c|c|c|c|c|c|c|c|c|}
\hline \multirow[t]{2}{*}{ Fungal species } & \multicolumn{2}{|l|}{ F1 } & \multicolumn{2}{|l|}{$\mathrm{F} 2$} & \multicolumn{2}{|l|}{ F3 } & \multicolumn{2}{|l|}{ P1 } & \multicolumn{2}{|l|}{ P2 } & \multicolumn{2}{|l|}{ P3 } \\
\hline & $\mathrm{RA}$ & FR & RA & FR & RA & FR & RA & FR & RA & FR & RA & FR \\
\hline Amanita muscaria (L.) Lam. & & & & & 1.6 & 13.3 & & & & & & \\
\hline Amanita spissa (Fr.) P. Kumm. & & & & & & & & & 7.1 & 16.7 & & \\
\hline Amphinema byssoides (Pers.) J. Erikss. & & & 0.5 & 3.3 & & & & & & & & \\
\hline Boletus edulis Bull. & 1.8 & 6.7 & & & 0.7 & 6.7 & & & & & & \\
\hline Boletus pruinatus $\mathrm{Fr}$. and Hök & & & 0.3 & 3.3 & 3.9 & 13.3 & & & & & & \\
\hline Byssocorticium sp. & & & & & & & 0.4 & 3.3 & & & & \\
\hline Cenococcum geophilum $\mathrm{Fr}$. & 25.2 & 46.7 & 7.4 & 13.3 & 2.7 & 16.7 & 12.7 & 30.0 & & & & \\
\hline Clavulina cristata (Holmsk.) J. Schröt & 4.3 & 10.0 & & & & & 45.8 & 50.0 & 31.0 & 33.3 & & \\
\hline Clavulina rugosa Bull. J. Schröt & & & & & & & & & & & 12.8 & 26.7 \\
\hline Clavulina sp. 1 & & & & & 1.4 & 10.0 & 4.4 & 3.3 & & & 1.0 & 3.3 \\
\hline Clavulina sp. 2 & & & & & & & & & 20.1 & 33.3 & & \\
\hline Cortinarius sp. 1 & & & & & 0.5 & 10.0 & & & & & & \\
\hline Cortinarius sp. 2 & & & 2.0 & 3.3 & 1.4 & 10.0 & & & & & & \\
\hline Elaphomyces muricatus Fr. & & & & & 2.1 & 6.7 & & & & & & \\
\hline Hydnotrya sp. & & & & & 2.8 & 6.7 & & & & & & \\
\hline Hydnum repandum $\mathrm{L}$. & & & 12.2 & 10.0 & & & & & & & & \\
\hline Hydnum rufescens Schaeff. & & & & & 2.3 & 3.3 & & & & & & \\
\hline Inocybe terrigena $(\mathrm{Fr}$.$) Kühner$ & 5.3 & 6.7 & & & & & & & & & & \\
\hline Laccaria amethystina (Huds.) Cooke & 3.9 & 10 & & & & & & & & & & \\
\hline Laccaria maritima (Theodor.) Singer ex Huhtinen & & & 4.8 & 16.7 & & & & & & & & \\
\hline Lactarius aurantiacus (Pers.) Gray & & & & & 8.2 & 30.0 & & & & & & \\
\hline Lactarius salmonicolor R. Heim and Leclair & 3.9 & 6.7 & 5.7 & 20.0 & & & & & & & & \\
\hline Leotiomycetes & & & & & 6.2 & 13.3 & & & & & & \\
\hline Paxillus involutus (Batsch) Fr. & & & & & 1.1 & 3.3 & & & & & & \\
\hline Piloderma byssinum (P. Karst.) Jülich & 5.3 & 10.0 & & & 0.9 & 3.3 & & & & & & \\
\hline Piloderma fallax (Lib.) Stalpers & & & & & 2.5 & 13.3 & & & & & & \\
\hline Pseudotomentella sp. & & & & & & & 2.8 & 6.7 & & & & \\
\hline Russula amethystina Quél. & & & 11.8 & 16.7 & 4.8 & 20.0 & & & & & & \\
\hline Russula integra (L.) Fr. & 5.7 & 16.7 & 2.6 & 6.7 & & & 10.4 & 26.7 & & & & \\
\hline Russula nigricans Fr. & & & 11.6 & 23.3 & & & & & & & & \\
\hline Russula olivacea (Schaeff.) Fr. & & & & & 5.7 & 23.3 & & & & & & \\
\hline Russula puellaris Fr. & & & & & & & & & & & 5.7 & 3.3 \\
\hline Russula xerampelina (Schaeff.) Fr. & & & & & & & 12.4 & 10.0 & & & & \\
\hline Sebacina sp. 1 & & & & & & & & & & & 6.1 & 13.3 \\
\hline Sebacina sp. 2 & & & & & 0.7 & 3.3 & & & & & & \\
\hline Sebacina sp. 3 & 8.2 & 13.3 & & & & & & & 11.4 & 6.7 & & \\
\hline Thelephora terrestris Ehrh. & & & & & & & & & & & 11.8 & 20.0 \\
\hline Thelephoraceae & & & & & & & & & & & 4.1 & 6.7 \\
\hline Tomentella ellisii (Sacc.) Jülich and Stalpers & & & & & & & & & 10.2 & 6.7 & & \\
\hline Tomentella sp. & 13.5 & 13.3 & & & & & & & & & 33.4 & 30.0 \\
\hline Tomentella stuposa (Link) Stalpers & 7.4 & 16.7 & 5.9 & 30.0 & 7.5 & 30.0 & 2.0 & 13.3 & 3.8 & 20.0 & 0.7 & 3.3 \\
\hline Tomentellopsis sp. & & & & & & & & & & & 4.1 & 13.3 \\
\hline Tuber puberulum Berk. and Broome & & & 3.3 & 6.7 & & & & & 16.5 & 23.3 & 6.4 & 13.3 \\
\hline Tuber sp. & & & & & & & 9.2 & 10.0 & & & & \\
\hline Tylospora asterophora (Bonord.) Donk & & & 7.0 & 23.3 & 6.8 & 16.7 & & & & & 5.1 & 10.0 \\
\hline Unidentified 1 & & & 24.8 & 56.7 & 35.1 & 70.0 & & & & & & \\
\hline Unidentified 2 & 12.1 & 13.3 & & & & & & & & & & \\
\hline Unidentified 3 & 3.5 & 3.3 & & & & & & & & & & \\
\hline Xerocomus badius (Fr.) Kühner & & & & & 1.1 & 3.3 & & & & & 8.8 & 10.0 \\
\hline
\end{tabular}


from the fir stands were unidentified fungus 1 (24.0\% in relative abundance), followed by C. geophilum (9.0\%), Russula amethystina (6.9\%), T. stuposa (6.8\%), and T. asterophora (5.6\%). Fir seedlings from the pine forecrops formed mycorrhizas mostly with C. cristata $(25.2 \%)$, Tomentella sp. (10.5\%), T. puberulum (8.9\%), and Clavulina sp. 1 (5.1 \%) (Fig. 3).

According to the ANOSIM similarity analysis, the ECM fungal communities differed $(R=0.1721 ; p=0.0001)$ between seedlings regenerated in the fir stands and pine forecrops; this was confirmed visually by NMDS analysis (Fig. 4).

\subsection{Soil parameters}

Table 1 provides soil parameters showing the $\mathrm{pH}$ value was similar among study sites, in the range of 4.3-5.7 in $\mathrm{H}_{2} \mathrm{O}$ and $3.3-4.8 \mathrm{in} \mathrm{KCl}$; the $\mathrm{C} / \mathrm{N}$ ratio had a range of $13.2-15.5$ between study sites. A high content of $\mathrm{Ca}$ and $\mathrm{Mg}$ was noted in the pine forecrops $\mathrm{P} 1$ and $\mathrm{P} 2$. The content of potassium had a range of $0.5-1.2$ in the $F$ sites to $0.7-8.2 \mathrm{mg} / \mathrm{kg}$ in the $P$ sites.

\section{Discussion}

Mycorrhizal colonization of fir seedlings was very similar to that of other coniferous trees (Aučina et al. 2011; Leski and Rudawska 2012; Teste et al. 2009). Sequencing analysis identified 49 ECM taxa associated with 1-year-old A. alba. In agreement with the present work, Comandini et al. (2001) classified a similar number of ECM morphotypes (48) on mature trees of $A$. alba in the Apennines. This stands in contrast to only 25 morphotypes found on seedlings at the same site (Comandini et al. 1998). Cremer et al. (2009) identified 33 taxa of $A$. alba symbionts in German forests by molecular means. Based on anatomical and morphological descriptions, Kowalski (2008) found 35 ECM types on silver

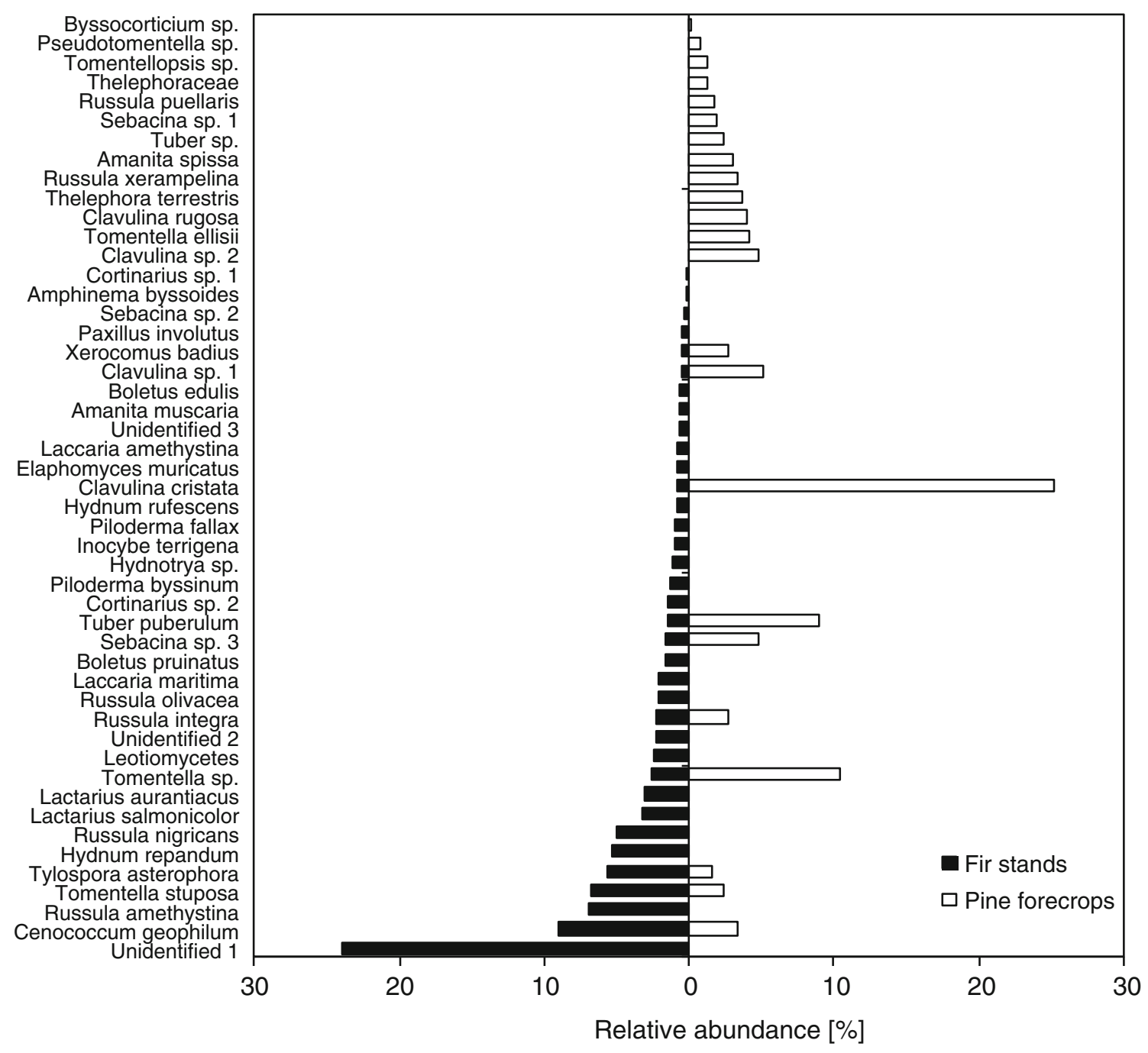

Fig. 3 Mean relative abundance of ectomycorrhizal fungi on 1-year-old Abies alba seedlings regenerating in fir stands and pine forecrops 
Fig. 4 Non-metric multidimensional scaling ordination of ectomycorrhizal fungal communities on 1-year-old Abies alba seedlings regenerating in fir stands (F1, F2, F3) and pine forecrops $(\mathrm{P} 1, \mathrm{P} 2, \mathrm{P} 3)$

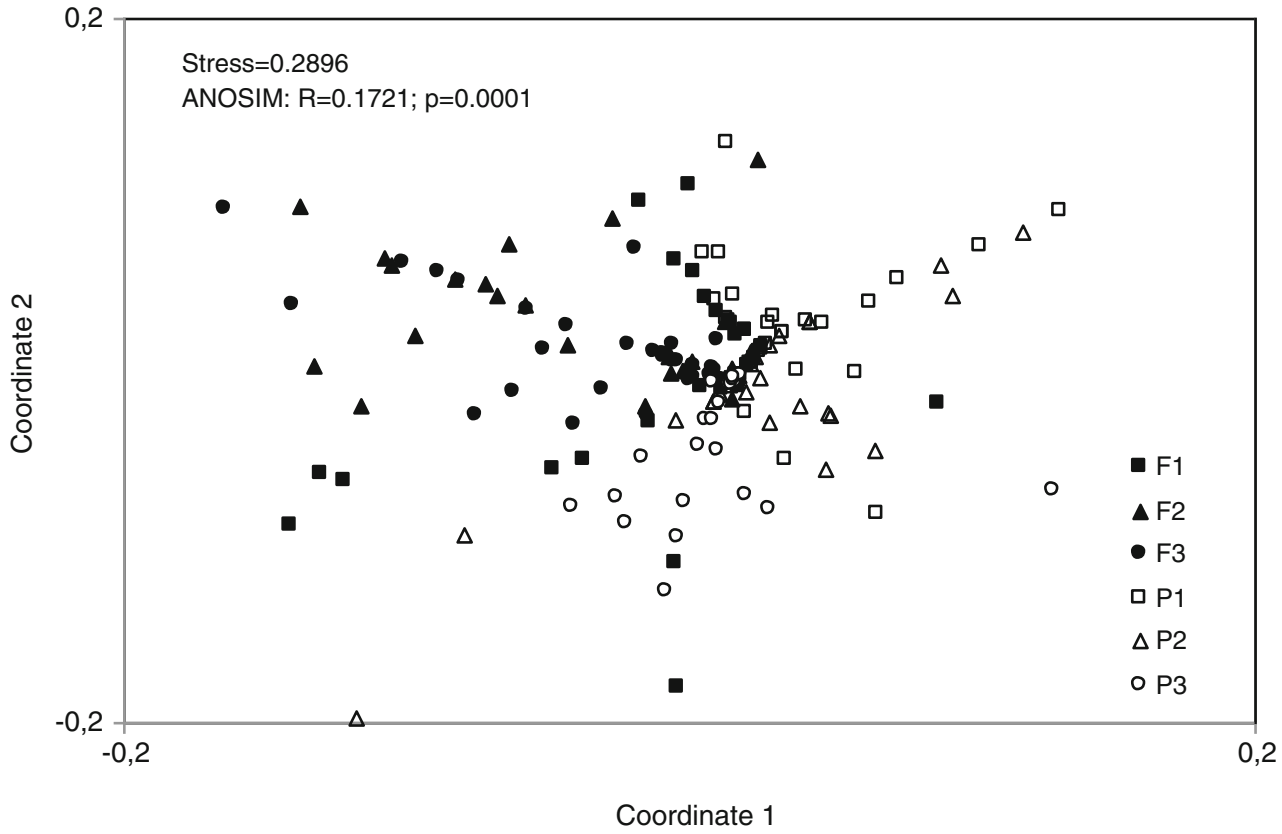

fir seedlings in the Karkonosze National Park (Poland). In a forest nursery, Stępniewska and Rębisz (2004) found only seven different types of ECM on fir seedlings.

Some of the ECM taxa described here have been recognized as symbionts of silver fir in previous studies, including: Amphinema byssoides, C. cristata (Cremer et al. 2009), Lactarius aurantiacus, Piloderma fallax, T. puberulum, T. asterophora (Smutek et al. 2010), Boletus pruinatus, C. geophilum, Laccaria amethystina, T. stuposa (Cremer et al. 2009; Smutek et al. 2010), and Lactarius salmonicolor (Agerer 1987-2007; Eberhardt et al. 2000). Some of the identified symbionts of silver fir have also been found as symbionts of other fir species. Kranabetter et al. (2009) identified C. geophilum, Amphinema byssoides, and T. cf. stuposa among the ECM symbionts of Abies lasiocarpa, whereas Matsuda and Hijii (1999, 2004) found C. geophilum, Russula spp., Lactarius spp., Tuber sp., and the thelephoroid fungus on Abies firma. ECM symbionts of Abies homolepis belonged mainly to the following genera: Amanita, Boletus, Cenococcum, Cortinarius, Inocybe, Laccaria, Lactarius, Russula, Sebacina, Tomentella, and Tuber (Ishida et al. 2007).

There were identified Clavulina rugosa and Inocybe terrigena as novel ECMs that were associated with $A$. alba. In addition, there were identified several ECM fungal species known to associate with other coniferous tree species from the genus Picea, Pinus, and Pseudotsuga and with deciduous species $F$. sylvatica as symbionts of silver fir for the first time on record. These ECM species were Amanita spissa (De Román et al. 2005), Boletus edulis (Korkama et al. 2006), Elaphomyces muricatus (Menkis et al. 2010), Hydnum rufescens (Agerer 1987-2007), Laccaria maritima (Lang et al. 2011), Russula nigricans, Russula xerampelina
(Agerer 1987-2007; Teste et al. 2009), and Tomentella ellisii (Obase et al. 2009).

The most predominant fungal taxon was T. stuposa, which was found in all sites. This was followed in frequency by C. geophilum, C. cristata, Clavulina sp.1, R. integra, T. asterophora, and T. puberulum, which were present at a minimum of three sites. These results agree with previous reports that identified $C$. geophilum and T. stuposa as frequent and abundant ECM symbionts of fir (Cremer et al. 2009). C. geophilum is ubiquitous and a dominating ECM species (Aučina et al. 2011; Teste et al. 2009). The genus Tomentella forms mycorrhizas with different tree species and develops morphotypes as has been frequently described in the literature (Jakucs and Erös-Honti 2008). In addition, the genus Tylospora, represented in this investigation by $T$. asterophora, is one of the most abundant genera-forming ectomycorrhizas on other coniferous tree species (i.e., P. abies) (Eberhardt et al. 1999).

A surprisingly high relative mean abundance $(25 \%)$ of ectomycorrhizas formed by $C$. cristata was detected on fir seedlings regenerating in pine forecrops. This finding was hypothesized to be a result of the high concentrations of $\mathrm{Ca}$ and $\mathrm{Mg}$ in the soil of P1 and P2 forecrops. Rineau and Garbaye (2009) showed that liming (Ca-Mg soil amendment) positively affects the development of $C$. cristata ectomycorrhizas in spruce (from 0 to $53 \%$ ) and beech (from 8 to $19 \%$ ) stands. The abundant brown mycorrhizas with the Hartig net and without a mantle were among the unidentified ECM morphotypes in fir stands. Molecular analysis revealed that this morphotype was made of various taxa; this suggests that the initial stadia of mycorrhiza of these taxa are similar and differ later on. For instance, this morphotype was not as frequent on 2-year-old $A$. alba seedlings (data not published). Nylund and Unestam (1982) reported that 
the Hartig net can appear before the fungal mantle. $L$. salmonicolor, one of the symbionts known to be specific to A. alba, was noted only in two sites and was not as frequent as in studies carried out in central Italy (Comandini et al. 2001).

ECM richness was significantly higher in particular fir stands (13-22) than in pine stands (7-12); this was also confirmed by Shannon-Wiener's and Simpson's diversity indices. According to the analysis of similarity, the ECM fungal communities on $A$. alba seedlings differed between fir and pine stands. Because common mycorrhizal networks (CMN) are present in forest soils (Kennedy et al. 2003; Teste et al. 2009), fir seedlings regenerating under a canopy of pine trees that are in close proximity to fir can be colonized by ECM fungi from mature silver fir trees in adjacent stands. However, in this case, because the pine and fir stands support different species of fungi, the seedlings in pine stands may be affected by pre-existing ECM communities of mature pine caused by the presence of CMN and spore banks.

Only $20 \%$ of symbionts of silver fir seedlings were common to fir and pine stands. This suggests that succession of ECM fungi specific to fir regenerating on formerly arable land had been afforested with pine about 50 years ago is ongoing and continues in the present day. Because silver fir invades under the canopy of pine forests, it is positioned to become the dominant plant species after the pines are lost in the future to competition. Natural regenerating and outplanted seedlings belong to the first age class; this may also indicate that these seedlings initially shared ECM with coexisting pine trees and became colonized by specific ECM many years after their establishment. Ishida et al. (2007) showed that the ECM community of Abies homolepis in the secondary forest site, which had been clear-cut over 70 years ago, more closely resembled the EMF communities of broadleaf trees from the same forest than that of A. homolepis in the primary oldgrowth forest.

It was found that ECM species richness was significantly lower in pine forecrops than in fir stands, but fungal colonization of seedling roots in pine forecrops was as high as in mature silver fir forest. The both hypotheses were confirmed. This suggests that the development of ECM of fir seedlings regenerating in pine stands afforested on formerly arable land allows these seedlings to survive and develop, enabling the potential process of secondary succession (Jaworski 2000).

This is the first report concerning ECM of $A$. alba seedlings regenerating in pine forecrops using molecular approaches. These results significantly increase our knowledge of the ECM fungal species associated with $A$. alba. Future work aimed at understanding why ECM fungal communities were different in seedlings of fir stands than those of pine forecrops will complement these findings. In addition, studying how differences in the pre-existing ECM fungal communities between fir stands and pine forecrops affect the mycorrhizal status and establishment of fir seedlings of different age classes in pine forecrops would be worthwhile. Such a study would provide more information on the diversity of ECM fungal partners of silver fir seedlings regenerating in pine stands on formerly arable areas and the possibilities of their successful regeneration.

Acknowledgements I would like to thank Prof. Stefan Kowalski for introducing me to ectomycorrhizas, for help with the investigations presented in this paper and for the valuable comments. I would also like to thank Prof. Maria Rudawska and Dr Tomasz Leski for help in molecular analysis of mycorrhizas. I would like to appreciate Prof. Katarzyna Turnau, Dr Piotr Rozpadek and anonymous reviewer for helpful comments on the manuscript and for revising the English.

Funding The present research was supported by the University of Agriculture in Kraków (Department of Forest Pathology), Project BZ 573/KFL (2008-2011). This paper was partly supported by the Jagiellonian University in Kraków funds DS/758/UJ.

Open Access This article is distributed under the terms of the Creative Commons Attribution License which permits any use, distribution, and reproduction in any medium, provided the original author(s) and the source are credited.

\section{References}

Abarenkov K, Nilsson RH, Larsson KH, Alexander IJ, Eberhardt U, Erland S, Høiland K, Kjøller R, Larsson E, Pennanen T, Sen R, Taylor AFS, Tedersoo L, Ursing BM, Vrålstad T, Liimatainen K, Peintner U, Kõljalg U (2010) The UNITE database for molecular identification of fungirecent updates and future perspectives. New Phytol 186:281-285

Agerer R (1987-2007) Colour atlas of ectomycorrhizae. Einhorn-Verlag Eduard Dietenberger, Schwäbisch Gmünd

Aučina A, Rudawska M, Leski T, Ryliškis D, Pietras M, Riepšas E (2011) Ectomycorrhizal fungal communities on seedlings and conspecific trees of Pinus mugo grown on coastal dunes of the Curonian Spit in Lithuania. Mycorrhiza 21:237-245

Berndt R, Kottke I, Oberwinkler F (1990) Ascomycete mycorrhizas from pot-grown silver-fir seedlings (Abies alba Mill.). New Phytol 115: 471-482

Bray JR, Curtis JT (1957) An ordination of the upland forest communities of southern Wisconsin. Ecol Monogr 27:325-349

Colwell RK (2006) EstimateS: statistical estimation of species richness and shared species from samples. Ver8. Persistent URL $<$ purl.oclc.org/estimates>

Comandini O, Pacioni G, Rinaldi AC (1998) Fungi in ectomycorrhizal associations of silver fir (Abies alba Miller) in central Italy. Mycorrhiza 7:323-328

Comandini O, Pacioni G, Rinaldi AC (2001) An assessment of belowground ectomycorrhizal diversity of Abies alba Miller in central Italy. Plant Biosyst 135:337-350

Cremer E, Donges K, Liepelt S, Rexer K-H, Vendramin GG, Leyer I, Kost G, Ziegenhagen B (2009) Ontogenetic and genotypic effects of silver fir (Abies alba Mill.) on associated ectomycorrhizal communities. In: Cremer E (ed) population genetics of silver fir (Abies alba .) in the Northern Black Forest - preconditions for the recolonization of wind throw areas and associated ectomycorrhizal communities. http://archiv.ub.uni-marburg.de/diss/z2009/0130/

De Román M, Claveria V, De Miguel AM (2005) A revision of the descriptions of ectomycorrhizas published since 1961. Mycol Res 109:1063-1104 
Dobrowolska D (2008) Growth and development of silver fir (Abies alba Mill.) regeneration and restoration of the species in the Karkonosze Mountains. J For Sci 54:398-408

Dominik T (1961) Badanie mikotrofizmu zespołów roślinnych w Parku Narodowym w Pieninach i na Skałce nad Łysa Polana w Tatrach ze szczególnym uwzględnieniem mikotrofizmu sosny reliktowej. Prace IBL 208:31-58

Eberhardt U, Walter L, Kottke I (1999) Molecular and morphological discrimination between Tylospora fibrillosa and Tylospora asterophora mycorrhizae. Can J Bot 77:11-21

Eberhardt U, Verbeken A, Rinaldi AC, Pacioni G, Comandini O (2000) Lactarius ectomycorrhizae on Abies alba: morphological description, molecular characterization and taxonomic remarks. Mycologia 92:860-873

Farfał D (2008) Root system vitality of natural and artificial regeneration of Silver fir in the Karkonosze National Park. In: Barzdajn W, Raj A (eds) Silver fir in the Karkonosze National Park, KPN Jelenia Góra, pp 87-104 (in polish)

Gardes M, Bruns TD (1993) ITS primers with enhanced specificity for basidiomycetes - application to the identification of mycorrhizae and rusts. Mol Ecol 2:113-118

Hall TA (1999) BioEdit: a user-friendly biological sequence alignment editor and analysis program for Windows 95/98/NT. Nucleic Acids Symp Ser 41:95-98

Hammer O, Harpener DAT, Ryan PD (2001) PAST: paleontological statistics software package for education and data analysis. Paleontol Electron 4:9

Horvat H, Glavač V, Ellenberg H (1974) Vegetation Südosteuropas. Fischer Verlag, Stuttgart

Ishida TA, Nara K, Hogets T (2007) Host effects on ectomycorrhizal fungal communities: insight from eight host species in mixed conifer-broadleaf forests. New Phytol 174:430-440

Jakucs E, Erős-Honti Z (2008) Morphological-anatomical characterization and identification of Tomentella ectomycorrhizas. Mycorrhiza 18:277-285

Jaworski A (2000) Zasady hodowli lasów górskich na podstawach ekologicznych. In: Poznański R, Jaworski A (eds) Nowoczesne metody gospodarowania w lasach górskich. CILP Warszawa, pp 194-203

Jaworski A (2011) Hodowla lasu, t. III. Charakterystyka hodowlana drzew i krzewów leśnych. PWRiL Warszawa, pp 154-203

Kennedy PG, Izzo AD, Bruns TD (2003) There is a high potential for the formation of common mycorrhizal networks between understorey and canopy trees in a mixed evergreen forest. J Ecol 91:10711080

Korkama T, Pakkanen A, Pennanen T (2006) Ectomycorrhizal community structure varies among Norway spruce (Picea abies) clones. New Phytol 171:815-824

Kowalski S (1982) Role of mycorrhiza and soil fungi community in natural regeneration of fir (Abies alba Mill.) in Polish Carpathians and Sudetes. Eur J For Pathol 12:107-112

Kowalski S (2008) Mycorrhizae of the European Silver fir (Abies alba Mill.) seedlings from natural and artificial regeneration in forests of the Karkonosze National Park. In: Barzdajn W, Raj A (eds) Silver fir in the Karkonosze National Park. KPN Jelenia Góra, pp 175-212 (in polish)

Kowalski S, Obłoza E, Kwiatkowski G (1996) A study on a mycotrophy of the European fir (Abies alba Mill.) in different forest communities in selected mountain forest stands. Zesz Nauk AR w Krakowie, nr 308. Leśnictwo 25:23-37 (in polish)

Kranabetter JM, Durall DM, MacKenzie WH (2009) Diversity and species distribution of ectomycorrhizal fungi along productivity gradients of southern boreal forest. Mycorrhiza 19:99-111

Laganà A, Loppi S, De Dominicis V (1999) Relationship between environmental factors and the proportions of fungal trophic groups in forest ecosystems of the central Mediterranean area. For Ecol Manag 124:145-151
Laganà A, Agnolini C, Loppi S, Salerni E, Perini C, Barluzzi C, De Dominicis V (2002) Periodicity, fluctuations of macrofungi in fir forests (Abies alba Mill.) in Tuscany, Italy. For Ecol Manag 169:187-202

Lanfranco L, Perotto S, Longato S, Mello A, Cometti V, Bonfante P (1998) Molecular approaches to investigate biodiversity in mycorrhizal fungi. In: Varma A (ed) Mycorrhiza manual. Springer, Berlin, pp 353-372

Lang C, Seven J, Polle A (2011) Host preferences and differential contributions of deciduous tree species shape mycorrhizal species richness in a mixed central European forest. Mycorrhiza 21:297-308

Leski T, Rudawska M (2012) Ectomycorrhizal fungal community of naturally regenerated European larch (Larix decidua) seedlings. Symbiosis 56:45-53

Maciaszek W, Zwydak M (1996) Transformation of mountain postagricultural soils by pioneer pine stands. Part I. Changes in the profile morphology and physical properties of soils. Acta Agr Silv ser Silv 34:67-79 (in polish)

Marx DH (1969) The influence of ectotrophic mycorrhizal fungi on the resistance of pine roots to pathogenic infections. I. Antagonism of mycorrhizal fungi to root pathogenic fungi and soil bacteria. Phytopathology 59:153-163

Matsuda Y, Hijii N (1999) Ectomycorrhizal morphotypes of naturally grown Abies firma seedlings. Mycoscience 40:217-226

Matsuda Y, Hijii N (2004) Ectomycorrhizal fungal communities in an Abies firma forest, with special reference to ectomycorrhizal associations between seedlings and mature trees. Can J Bot 82:822-829

Menkis A, Uotila A, Arhipova N, Vasaitis R (2010) Effects of stump and slash removal on growth and mycorrhization of Picea abies seedlings outplanted on a forest clear-cut. Mycorrhiza 20:505-509

Nylund JE, Unestam T (1982) Structure and physiology of ectomycorrhizae. I. The process of mycorrhiza formation in Norway spruce in vitro. New Phytol 91:63-79

Obase K, Cha JY, Lee JK, Lee SY, Lee JH, Chun KW (2009) Ectomycorrhizal fungal communities associated with Pinus thunbergii in the eastern coastal pine forest of Korea. Mycorrhiza 20:39-49

Ostrowska A, Gawliński S, Szczubiałka Z (1991) Metody analizy i oceny właściwości gleb i roślin. Warszawa

Pachlewski R (1955) Badania mikotrofizmu jodły pospolitej (Abies alba Mill.) w naturalnych zespołach Gór Świętokrzyskich. Roczn Nauk Leśn 139:111-129

Perry DA, Amaranthus MP, Borchers JG, Borchers SL, Brained RE (1989) Bootstrapping in ecosystems. Bioscience 39:230-237

Rineau F, Garbaye J (2009) Does forest liming impact the enzymatic profiles of ectomycorrhizal communities through specialized fungal symbionts? Mycorrhiza 19:493-500

Smutek I, Rudawska M, Leski T (2010) Ektomikoryzy — ukryty potencjał w badaniach mikobioty drzew leśnych na przykładzie drzewostanów jodłowych. http://www.czlowiekiprzyroda.eu/Ksiazki/74.pdf

StatSoft, Inc (2011) STATISTICA (data analysis software system), version 10.0. www.statsoft.com

Stępniewska H, Rębisz P (2004) Mycorrhizae of fir (Abies alba Mill.) seedlings growing on sawdust - peat substrates of different periods of utilization. Sylwan 8:34-42 (in polish)

Teste FP, Simard SW, Durall DM (2009) Role of mycorrhizal networks and tree proximity in ectomycorrhizal colonization of planted seedlings. Fungal Ecol 2:21-30

Trappe JM (1962) Fungus associates of ectotrophic mycorrhizae. Bot Rev 28:538-606

Ważny R (2011) Mycorrhizas of Abies alba Mill. natural regeneration from forest stands in Experimental Forestry Unit in Krynica. Episteme 12(II):89-96 (in polish)

White TJ, Bruns T, Lee S, Taylor J (1990) Amplification and direct sequencing of fungal ribosomal RNA genes for phylogenetics. In: Innis MA, Gelfand DH, Sninsky JJ, White TJ (eds) PCR protocols: a guide to methods and applications. Academic, London, pp 315-322 